\title{
Pitfalls in Cross-Section Studies with integrated Regressors: Survey and New Developments
}

Stelios Bekiros, Bo Sjö and Richard J. Sweeney

The self-archived postprint version of this journal article is available at Linköping University Institutional Repository (DiVA):

http://urn.kb.se/resolve?urn=urn:nbn:se:liu:diva-145627

N.B.: When citing this work, cite the original publication.

Bekiros, S., Sjö, Bo, Sweeney, R. J., (2018), Pitfalls in Cross-Section Studies with integrated Regressors: Survey and New Developments, Journal of economic surveys (Print), 1-29.

https://doi.org/10.1111/joes.12246

Original publication available at:

https://doi.org/10.1111/joes.12246

Copyright: Wiley (24 months)

http://eu.wiley.com/WileyCDA/ 


\title{
Pitfalls in Cross-Section Studies With InTEgrated REGRESSORS: A SURVEY AND NEW DEVELOPMENTS Stelios Bekiros, Bo Sjö, and Richard J. Sweeney
}

\begin{abstract}
In cross-section studies, if the dependent variable is $\mathrm{I}(0)$ but the regressor is $\mathrm{I}(1)$, the true slope must be zero in the resulting "unbalanced regression." A spuriously significant relationship may be found in large cross sections, however, if the integrated regressor is related to a stationary variable that enters the DGP but is omitted from the regression. The solution is to search for the related stationary variable, in some cases the first difference of the integrated regressor, in other cases a categorical variable that can take on limited number of values which depend on the integrated variable. We present an extensive survey, new developments and applications in finance.
\end{abstract}

Keywords: unbalanced regressions; unit roots; categorical variables; stock appreciation; survey JEL Classification: C31; C32; G1 


\section{INTRODUCTION AND LITERATURE REVIEW}

Cross-section studies frequently use "unbalanced" regressions, where a stationary dependant variable is regressed on an integrated explanatory variable, for example, a rate of return is regressed on size. There are severe problems in unbalanced regressions, however: In an unbalanced regression, the true slope on the integrated regressor is necessarily zero. Thus, in the many studies that estimate unbalanced regressions and report statistically significant slopes, the significance is necessarily spurious. This paper shows that, aside from sampling variability, the spurious significance arises under two conditions. First, the data contain a true relationship between the stationary dependent variable and an omitted stationary explanatory variable that is related to the integrated regressor - the integrated regressor is a proxy variable for the omitted stationary independent variable. Second, the omitted stationary variable and the related integrated variable show small but true correlation. For example, the stationary explanatory variable in the true relationship may be the first difference of the integrated regressor, for example, the first difference of earnings rather than the level of earnings. In finite samples the change in earnings must show a small but true, positive correlation with the level of earnings; the true finite-sample correlation depends inversely on the number of changes in earnings that compose the level of earnings, and goes to zero as this number grows large. Or the stationary explanatory variable in the true relationship may be a categorical variable which can take on a limited number of values that are related to the integrated regressor, for example, "large" versus "small" firms rather than firm size, or "young" versus "older" firms rather than firm age. Size does not affect returns but does affect the category into which a firm falls. Unsurprisingly, the larger is the cross section, the more likely is the spurious relationship to show significance. Further, as is to be expected, all these points fully apply to panels with large cross sections $\mathrm{N}$ but few time-series observations $\mathrm{T}$, where asymptotic results rely on $\mathrm{N}$ growing large; this situation applies to the great majority of corporate finance studies. Finally, this paper provides step-by-step procedures to deal 
with unbalanced regressions: It discusses how to avoid problems, to diagnose problems and to remedy problems.

The problem discussed here arises frequently in finance. For example, many prestigious Journals in finance and econometrics had 86 articles and notes e.g., Journal of Finance (2005); 62 are cross-section studies or panel studies, and 42 of these are subject to the problem discussed here (please see Appendix II). All use stationary dependent variables, and 37 use regressors that are nonstationary, such as price, size in market value or accounting terms, or cash flows, invested capital or earnings, as Table 1 shows. 15 use trend-like explanatory variables, such as time or age. 18 use ratios that may well be non-stationary, given that data cannot reject the null that the rate of return on equity and also the rate of return on invested capital are integrated (Siddique and Sweeney, 2006); ${ }^{1}$ all but four of these 18 articles are also included in one of the other categories.

Regressing a stationary variable on a integrated variable is a misspecification, which can lead the researcher astray in two ways. (a) The researcher may find no relationship - the true slope is necessarily zero in the unbalance regression. The researcher may abandon this avenue, thus missing any true relationship between the stationary dependent variable and a stationary explanatory variable which is related to the integrated regressor. (b) If the integrated regressor is related to an omitted stationary variable that enters the true relationship, the slope may be spuriously significant, as discussed in detail and illustrated by examples below; this is more likely to arise the larger is the cross section. The researcher may stop his search here, thus missing the true relationship between the stationary dependent variable and the omitted stationary variable.

This paper's points are theoretical and must hold under specified, general conditions; these points are presented as theorems, but examples below with actual data and with simulated data illustrate the theoretical points. One empirical example investigates OLS regressions of share-price

\footnotetext{
${ }^{1}$ Common microstructure variables, not included in the sample may be I(1). For volumes of Dow-30 firms the data cannot reject the unit-root null; if volume is I(1), the number of trades or shares per trade must be I(1).
} 
appreciation on the change in earnings versus the levels of earnings; the level of earnings is supposed to capture earnings-persistence effects on price appreciation, as Ohlson and Shroff (1992) suggest and Easton and Harris (1991) suggest and investigate. Another example is a simulation where the true relationship's conditional expectation is between rates of return and the size category into which a firm falls: The mean is larger for small firms in the lower half of the size distribution than for large firms in the upper half of the size distribution, but within each half returns are uncorrelated with size. Because the rate of return is stationary but log size is integrated, the true slope is zero, but a OLS regression is likely to find a significant but spurious relationship.

The researcher may argue that the time series available are too short for meaningful unit-root tests; some panel approaches, however, do not require long time series (Breitling and Meyer, 1994; Levin and Lin, 1992; Im, Pesaran and Shin, 2003). (Later approaches allow for cross-sectional dependence, for example, Bai and Ng, 2004; Pesaran, 2007; Demetrescu and Hanck, 2012; Hanck and Czuda, 2015)Further, the literature provides substantial time-series evidence on some of the variables used in cross section studies, for example, firm size, assets, etc. In addition, in doubtful cases the researcher might replace the suspect variable with a related stationary variable, for example, the first difference or a related categorical variable.

In the following, Sections 2 and 4 show that if the dependent variable is $I(0)$ and an explanatory variable is $\mathrm{I}(1)$, then the true slope on the I(1) regressor is necessarily zero. The estimated slope may be significant, however. Suppose an I(0) explanatory variable enters the true model importantly, but is omitted in estimation. Instead, the I(1) regressor is included and is related to the omitted $\mathrm{I}(0)$ regressor; the I(1) regressor acts as a proxy variable for the omitted $\mathrm{I}(0)$ explanatory variable. Unsurprisingly, the relationship is more likely to be significant the larger is the cross section. Section 2 discusses the case where the dependent variable, the omitted $\mathrm{I}(0)$ variable and the $\mathrm{I}(1)$ regressor are continuous (i.e., can take on any real value); in section 3, data on stock prices and earnings illustrate 
how spurious significance can arise in this case in cross-section regressions. Alternatively, section 4 shows that the omitted variable may a categorical variable (i.e., can take on a limited number of values) where the category a firm is in is related to the $\mathrm{I}(1)$ regressor; section 5 provides an example from simulation, where a firm's rate of return depends on the half of the size distribution the firm is in, but the researcher regresses returns on lagged size. Section 6 offers a summary and some conclusions.

\section{2. "Unbalanced Regressions": An I(0) VARIAble IS REgReSSED ON AN I(1) VARIAble}

In cross-section and panel studies, researchers often do not consider the persistence of the explanatory variables. Indeed, Wooldridge (2002, section 7.8.3, p. 175) offers the view: "[W]e do not need to restrict the dynamic behavior of our data in any way because we are doing fixed-T, large$\mathrm{N}$ asymptotics." 2 This view is incorrect in the unbalanced regression case.

The Model: Let the dependent and independent variables be $\mathrm{y}_{\mathrm{jt}} \sim \mathrm{I}(0) \sim \Delta \mathrm{x}_{\mathrm{jt}}$, the conditional expectation $\mathrm{E}\left(\mathrm{y}_{\mathrm{jt}} \mid \Delta \mathrm{x}_{\mathrm{jt}}\right)$ be

$$
\mathrm{y}_{\mathrm{jt}}=\alpha+\beta \Delta \mathrm{x}_{\mathrm{jt}}, \quad \mathrm{j}=1, \ldots, \mathrm{N}, \mathrm{t}=\mathrm{T}^{\prime}, \ldots, \mathrm{T}
$$

$\beta>0, \alpha>/<0$, and the error be $\mathrm{u}_{\mathrm{jt}} \sim$ iid $\left(0, \sigma_{\mathrm{u}}^{2}\right), \mathrm{E}\left(\Delta \mathrm{x}_{\mathrm{jt}} \mathrm{u}_{\mathrm{jt}}\right)=0 .{ }^{3}$ Thus, the Data Generating Process (DGP) is

$$
\mathrm{y}_{\mathrm{jt}}=\alpha+\beta \Delta \mathrm{x}_{\mathrm{jt}}+\mathrm{u}_{\mathrm{jt}}, \quad \mathrm{j}=1, \ldots, \mathrm{N}, \mathrm{t}=\mathrm{T}^{\prime}, \ldots, \mathrm{T}
$$

This DGP is internally consistent in the sense that all variables are $\mathrm{I}(0)$.

Intuition for the Slope of an I(1) Regressor: (2) holds for all j,t. Focus on unit $\mathrm{j}$ (a household or

\footnotetext{
${ }^{2}$ Hayashi (2000, pp. 198, 261), however, assumes the unique, non-constant variables are ergodic and stationary. For panel estimation, Hsiao (2003, pp. 107-108) presents a demonstration that "The GMM estimator is consistent and asymptotically normally distributed as $\mathrm{N} \rightarrow \infty$ if all the roots ... fall outside the unit circle, but breaks down if some roots are equal to unity."

${ }^{3}$ With cross correlations of the errors, OLS understates the slope's standard error and overstates its t-value; mutatis mutandis this paper's key points remain valid. Note that if cross correlations are due to fixed-time effects affecting all firms, the cross-section regression automatically removes such effects, and in a panel the researcher can remove fixedtime effects (Hsiao 2003, pp. 28-33; Im, Pesaran and Shin, 2003; Levin and Lin, 1992; Levin et al., 2002); the panel is unlikely to be large enough to allow removal of time-constant firm effects, but the researcher can likely remove industry effects.
} 
firm, etc.) in the panel. Denote the sample variance and covariance operators by var and cov; then $\operatorname{var}\left(\mathrm{y}_{\mathrm{jt}}\right) \sim \mathrm{I}(0) \sim \operatorname{var}\left(\mathrm{u}_{\mathrm{it}}\right)$ because $\operatorname{var}\left(\mathrm{u}_{\mathrm{jt}}\right) \rightarrow^{\mathrm{p}}{\sigma^{2}}_{\mathrm{u}}$ and $\operatorname{var}\left(\mathrm{y}_{\mathrm{jt}}\right) \rightarrow^{\mathrm{p}} \beta{\sigma^{2}}_{\Delta \mathrm{x}}+\sigma_{\mathrm{u}}^{2}$. $\operatorname{var}\left(\mathrm{x}_{\mathrm{it}}\right) \sim \mathrm{I}(1)$, however: as $t$ grows large, $\operatorname{var}\left(\mathrm{x}_{\mathrm{jt}}\right)$ grows without limit because $\mathrm{x}_{\mathrm{it}} \sim \mathrm{I}(1) .{ }^{4}$ Thus, in a relationship of $\mathrm{y}_{\mathrm{t}}$ to $\mathrm{x}_{\mathrm{t}}$ the true slope must be zero (Banerjee et al., 1993).

THEOREMS: For the DGP in (2), consider two OLS cross-section or panel regressions,

$$
\begin{aligned}
& y_{j t}=\mathrm{a}+\mathrm{b} \Delta \mathrm{x}_{\mathrm{jt}}+\mathrm{z}_{\mathrm{jt}}, \quad \mathrm{j}=1, \ldots, \mathrm{N}, \mathrm{t}=\mathrm{T}^{\prime}, \ldots, \mathrm{T} \\
& \mathrm{y}_{\mathrm{jt}}=\mathrm{a}+\mathrm{g} \mathrm{x}_{\mathrm{jt}}+\mathrm{z}_{\mathrm{jt}}, \quad \mathrm{j}=1, \ldots, \mathrm{N}, \mathrm{t}=\mathrm{T}^{\prime}, \ldots, \mathrm{T}
\end{aligned}
$$

where $z_{j t}$ is a residual,

$$
\begin{gathered}
\hat{\mathrm{b}}=\beta+\operatorname{cov}\left(\Delta \mathrm{x}_{\mathrm{jt}}, \mathrm{u}_{\mathrm{jt}}\right) / \operatorname{var}\left(\Delta \mathrm{x}_{\mathrm{jt}}\right) \\
\mathrm{t}_{\mathrm{b}}=\left[\beta \operatorname{cov}\left(\Delta \mathrm{x}_{\mathrm{jt}}, \Delta \mathrm{x}_{\mathrm{jt}}\right)+\operatorname{cov}\left(\mathrm{x}_{\mathrm{jt}}, \mathrm{u}_{\mathrm{jt}}\right)\right] / \mathrm{N}^{-1 / 2} \operatorname{var}\left(\hat{\mathrm{z}}_{\mathrm{jt}}\right)^{1 / 2} \operatorname{var}\left(\Delta \mathrm{x}_{\mathrm{jt}}\right)^{1 / 2} \\
\hat{\mathrm{g}}=\operatorname{cov}\left(\mathrm{x}_{\mathrm{jt}}, \mathrm{u}_{\mathrm{jt}}\right) / \operatorname{var}\left(\mathrm{x}_{\mathrm{jt}}\right)=\left[\operatorname{cov}\left(\mathrm{x}_{\mathrm{jt}}, \beta \Delta \mathrm{x}_{\mathrm{jt}}\right) / \operatorname{var}\left(\mathrm{x}_{\mathrm{jt}}\right)\right]+\left[\operatorname{cov}\left(\mathrm{x}_{\mathrm{jt}}, \mathrm{u}_{\mathrm{jt}}\right) / \operatorname{var}\left(\mathrm{x}_{\mathrm{jt}}\right)\right] \\
=\left[\operatorname{cov}\left(\Delta \mathrm{x}_{\mathrm{jt}}, \beta \Delta \mathrm{x}_{\mathrm{jt}}\right) / \operatorname{var}\left(\mathrm{x}_{\mathrm{jt}}\right)\right]+\left[\operatorname{cov}\left(\mathrm{x}_{\mathrm{jt}-1}, \Delta \mathrm{x}_{\mathrm{jt}}\right) / \operatorname{var}\left(\mathrm{x}_{\mathrm{jt}}\right)\right]+\left[\operatorname{cov}\left(\mathrm{x}_{\mathrm{jt}}, \mathrm{u}_{\mathrm{jt}}\right) / \operatorname{var}\left(\mathrm{x}_{\mathrm{jt}}\right)\right] \\
\mathrm{t}_{\mathrm{g}}=\left[\beta \operatorname{cov}\left(\Delta \mathrm{x}_{\mathrm{jt}}, \Delta \mathrm{x}_{\mathrm{jt}}\right)+\beta \operatorname{cov}\left(\mathrm{x}_{\mathrm{jt}-1}, \Delta \mathrm{x}_{\mathrm{jt}}\right)+\operatorname{cov}\left(\mathrm{x}_{\mathrm{jt}}, \mathrm{u}_{\mathrm{jt}}\right)\right] / \mathrm{N}^{-1 / 2} \operatorname{var}\left(\hat{\mathrm{z}}_{\mathrm{jt}}\right)^{1 / 2} \operatorname{var}\left(\mathrm{x}_{\mathrm{jt}}\right)^{1 / 2}
\end{gathered}
$$

It is useful to state results in the theorem-proof format; the proofs are presented in Appendix I.

THEOREM 1 (included for completeness): plim $\hat{\mathrm{b}}=\beta>0$; as $N \rightarrow \infty$, then $\hat{\mathrm{b}} \rightarrow \beta>0$. Moreover, plim $t_{g}=\beta N^{1 / 2}>0 ; \quad$ as $N \rightarrow \infty$, then $t_{g} \rightarrow^{d} \beta N^{1 / 2}+N(0,1)$.

Next, write $\mathrm{x}_{\mathrm{j} T}=\sum_{\mathrm{h}=\mathrm{T}^{\prime}}^{\mathrm{T}} \Delta \mathrm{x}_{\mathrm{jh}}$, where the sample's initial time period $\mathrm{T}^{\prime}, \mathrm{x}_{\mathrm{j}, \mathrm{T}^{\prime}-1}=0$ for convenience, and the process generating $\mathrm{x}_{\mathrm{j}}$ has run $G_{T}$ periods, $\mathrm{G}_{\mathrm{T}}=\mathrm{T}-\mathrm{T}^{\prime \prime}, \mathrm{T}^{\prime} \leq \mathrm{T}^{\prime \prime}$. Thereafter, the subscript $\mathrm{T}$ in $G_{T}$ is dropped where this causes no confusion.

THEOREM 2: plim $\hat{\mathrm{g}}=\beta / G>0$; as $N \rightarrow \infty$, then $\hat{\mathrm{g}} \rightarrow^{d}(\beta / G)+(N G)^{-1 / 2}\left(\sigma_{u}^{2} / \sigma_{\Delta x}\right) N_{u, \Delta x}(0,1)+$ $\left(N G_{T}\right)^{-1 / 2}(1-1 / G)^{-1 / 2} \sigma_{\Delta x} N_{\Delta x, x}(0,1)$. Furthermore, plim $t_{g}=\beta\left(\sigma_{\Delta x} / \sigma_{u}\right)(N / G)^{1 / 2} /\left[(1-1 / G)\left(\sigma_{\Delta x}^{2}\right.\right.$ $\left.\left./ \sigma_{u}^{2}\right)+1\right]^{1 / 2}>0$; as $N \rightarrow \infty$, then $t_{g} \rightarrow^{d} \beta\left(\sigma_{\Delta x} / \sigma_{u}\right)(N / G)^{1 / 2} /\left[(1-1 / G)\left(\sigma_{\Delta x}^{2} / \sigma_{u}^{2}\right)+1\right]^{1 / 2}+N(0$,

\footnotetext{
${ }^{4}$ The assumptions about the error $\mathrm{u}_{\mathrm{jt}}$ and $\Delta \mathrm{x}_{\mathrm{jt}}$ (below) imply $\mathrm{y}_{\mathrm{t}}$ shows no persistence. In cases where the $\mathrm{y}_{\mathrm{jt}} \sim \mathrm{I}(0) \sim \Delta \mathrm{x}_{\mathrm{jt}}$ show persistence, a footnote below illustrates that nevertheless plim $\hat{\mathrm{g}}=0$.
} 
1) $\left\{\left(1+\sigma_{\Delta x}^{2} / \sigma_{u}^{2}\right) /\left[\left(1-1 / G_{T}\right)\left(\sigma_{\Delta x}^{2} / \sigma_{u}^{2}\right)+1\right]\right\}^{1 / 2}$

(The notation $\mathrm{N}_{\mathrm{u}, \Delta \mathrm{x}}(0,1)$ signifies the standard normal associated with the interaction of $\mathrm{u}_{\mathrm{jt}}$ with $\Delta \mathrm{x}_{\mathrm{jt}}$ )

Use an I(0) or I(1) Regressor?: If the I(1) variable's estimated slope is significant, the researcher should not stop there. In general the true relationship is between the dependent variable and an omitted I(0) independent variable that shows sample correlation with the included I(1) regressor. Use of the correct $\mathrm{I}(0)$ regressor gives a slope that is asymptotically larger $[\beta>(\beta / \mathrm{G})$ for $\mathrm{G} \geq 2$ ], and a t-value with a larger plim.

I(1)Regressors and Empirical Puzzles: Using an I(1) regressor can cause needless puzzles in empirical results. As noted, if the regressor is I(1), the estimated slope is expected to be relatively small $(\beta / G$ rather than $\beta$ ). Frequently, the researcher reports a slope that seems puzzlingly small; this is to be expected because plim $\hat{\mathrm{g}}=\beta / \mathrm{G}$ rather than $\beta$ (Theorem 2). Related, in reviewing studies that use moderate cross sections, say $\mathrm{N}=50$ or $\mathrm{N}=100$, researchers may find that $\hat{\mathrm{g}}$ tends to be positive (from $\beta>0$ ) across samples but with insignificant t-values, and may find that significance at conventional levels is associated with surprisingly large samples; both phenomena are be expected, however, because $\mathrm{tg}_{\mathrm{g}}$ depends on $(\mathrm{N} / \mathrm{G}){ }^{1 / 2}$ rather than $\mathrm{N}^{1 / 2}$.

Simulation results in Table 2 illustrate these points. In the DGP, $\beta=0.177701$, an estimate that Table 3 reports and section 4 discusses, for an experiment where both variables are stationary; the variances of $\mathrm{y}_{\mathrm{jt}}, \Delta \mathrm{x}_{\mathrm{jt}}$ and $\mathrm{u}_{\mathrm{jt}}$ are taken from the same experiment. Results are reported for crosssection unbalanced regressions where $\mathrm{N}$ ranges from 50 to 1000 , and $\mathrm{G}$ is either 10 or 20 . For a moderate cross section $\mathrm{N}=100$ with the larger $\mathrm{G}=20$, the mean $\hat{\mathrm{g}}$ is positive but small-only 0.008600 - and the mean t-value is only 0.59697 . Keeping $\mathrm{G}=20$, the cross section must increase to $\mathrm{N}=1000$, for the mean $\mathrm{t}$-value to rise to 1.95214 , borderline significant at the $5 \%$ level. ${ }^{5}$ Thus, the researcher who works diligently to make $\mathrm{N}$ very large is likely to find significant results - though the 
true slope is zero. A key empirical issue, taken up in section 4, is the likely value of G.

Unbalanced Regressions: Time-Series vs. Cross-Section Problems In time-series analysis, asymptotically the distributions of $\hat{\mathrm{g}}$ and $\mathrm{t}_{\mathrm{g}}$ are generally non-normal; in cross-section analysis, $\hat{\mathrm{g}}$ and $\mathrm{t}_{\mathrm{g}}$ are normal but $\mathrm{E} \hat{\mathrm{g}}$, $\mathrm{E} \mathrm{tg}_{\mathrm{g}}$ do not go to zero (for $\beta \neq 0$ ). Consider again the DGP

$$
\mathrm{y}_{\mathrm{jt}}=\alpha+\beta \Delta \mathrm{x}_{\mathrm{jt}}+\mathrm{u}_{\mathrm{jt}}, \quad \mathrm{j}=1, \ldots, \mathrm{N}, \quad \mathrm{t}=\mathrm{T}^{\prime}, \ldots, \mathrm{T}
$$

For time-series purposes, let $\mathrm{j}=1$. Then, in the regression

$$
y_{j t}=a+g_{j t}+z_{j t}, \quad j=1, \quad t=T^{\prime}, \ldots, T
$$

$\hat{\mathrm{g}}$ is super-consistent and as $\mathrm{T}$ grows large, $\mathrm{E} \hat{\mathrm{g}} \rightarrow 0$; the distribution of $\hat{\mathrm{g}}$ in normal, however, only if the innovation in $\mathrm{x}_{\mathrm{jt}}$ (i.e., $\Delta \mathrm{x}_{\mathrm{jt}}$ in this case) has zero long-run correlation with the error $\mathrm{u}_{\mathrm{jt}}$. Related, the distribution of $\mathrm{t}_{\mathrm{g}}$ is asymptotically standard normal only if $\Delta \mathrm{x}_{\mathrm{jt}}$ has zero long-run correlation with the error $\mathrm{u}_{\mathrm{jt}}$. For cross-section purposes, let $\mathrm{t}=\mathrm{T}$. Then, in the regression

$$
\mathrm{y}_{\mathrm{jt}}=\mathrm{a}+\mathrm{g} \mathrm{x}_{\mathrm{jt}}+\mathrm{z}_{\mathrm{jt}}, \quad \mathrm{j}=1, \ldots, \mathrm{N}, \quad \mathrm{t}=\mathrm{T}
$$

from Theorem 2, as $\mathrm{N}$ grows large $\hat{\mathrm{g}} \rightarrow\left(\beta / \mathrm{G}>0\right.$, plim $\mathrm{t}_{\mathrm{g}} \rightarrow \infty$, and both $\hat{\mathrm{g}}$ and $\mathrm{t}_{\mathrm{g}}$ are normal.

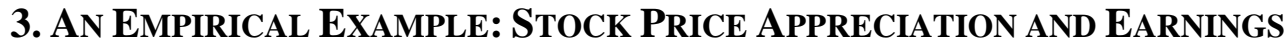

Earnings play a key role in virtually all valuation models. In the Residual Income (RI) model, earnings and book are the drivers of a firm's equity value. In free cash flow (FCF) models of overall firm value, FCFs are a key driver; ceteris paribus, earnings have a one-to-one effect on FCFs. Authors sometimes consider two channels through which earnings may affect share prices (Easton and Harris, 1991; Ohlson and Shroff, 1992) and present results from testing both (Easton and Harris, 1991). In one channel, a firm's stock price appreciation depends positively on its contemporaneous growth rate in earnings. In a second channel price appreciation depends positively on earnings

\footnotetext{
${ }^{5}$ The mean $\hat{g}$ remains quite small at 0.008907 , as expected from $\operatorname{plim} \hat{\mathrm{g}}=\beta / \mathrm{G}$, independent of $\mathrm{N}$.
} 
persistence. The first channel suggests the cross-section estimating equation

$$
\Delta \ln P_{j t}=a+b \Delta \ln X_{j t}+z_{j t}, \quad X_{j, t}, X_{j, t-1}>0, \quad j=1, N, \quad t=1996
$$

and the second channel suggests

$$
\Delta \ln P_{j t}=a+g \ln X_{j t}+z_{j t}, \quad X_{j, t}>0, \quad j=1, N, \quad t=1996
$$

where $\mathrm{z}_{\mathrm{jt}}$ is a residual, $\mathrm{P}_{\mathrm{jt}}$ is firm $\mathrm{j}$ 's share price at time and $\mathrm{X}_{\mathrm{jt}}>0$ its earnings per share, $\Delta \ln \mathrm{P}_{\mathrm{jt}} \equiv \ln \mathrm{P}_{\mathrm{jt}}$ - $\ln \mathrm{P}_{\mathrm{jt}-1}, \Delta \ln \mathrm{X}_{\mathrm{jt}} \equiv \ln \mathrm{X}_{\mathrm{jt}}-\ln \mathrm{X}_{\mathrm{jt}-1}$; thus, this paper considers only firms with positive earnings, a common restriction. ${ }^{6}$ The errors are assumed homoskedastic with no cross correlation. ${ }^{7}$ Because $\Delta \ln \mathrm{P}_{\mathrm{jt}} \sim \mathrm{I}(0) \sim \Delta \ln \mathrm{X}_{\mathrm{jt}}$, and $\ln \mathrm{X}_{\mathrm{jt}} \sim \mathrm{I}(1),(3)$ is a balanced regression and (4) is unbalanced.

As an example, Table 3 (panels A and B) shows results for 1996; this year was chosen randomly from among the data set: The earnings, price and book data used here are from thirty-one-years worth of data drawn from Compustat, for firms with yearly observations in 1980-2000. In (3), with $\mathrm{N}=991$, the slope (t-value, p-value) is 0.177701 (13.70773, 0.0000); in (4), with the same firms, the slope (t-value, p-value are) 0.020529 (1.972933, 0.0488), a weaker relationship but significant at the $5 \%$ level. Compared to (3), the slope in (4) is only $11.55 \%$ as large, the t-value only $14.39 \%$ as large and the $\mathrm{R}^{2}$ only $2.455 \%$ as large. ${ }^{8}$ Results for the 1995 cross section are similar, though the slope on $\ln \mathrm{X}_{\mathrm{j}, 1995}$ has a larger $\mathrm{t}$-value, 3.259458. For a panel that includes both years, or $\mathrm{t}=1995,1996$, results in Table 3.C illustrate that this paper's points regarding cross sections apply directly to panels with small T.9, 10

\footnotetext{
${ }^{6}$ Many papers focus on positive earnings; negative earnings, if considered, are virtually always treated separately.

${ }^{7}$ In estimation, only firms with $\mathrm{X}_{\mathrm{jt}}, \mathrm{X}_{\mathrm{jt}-1}>0$ are considered; further, book values $\mathrm{B}_{\mathrm{jt}-1}>0$ and $\mathrm{B}_{\mathrm{jt}-2}>0$ are also required, jointly implying that the return on equity is positive, $\mathrm{ROE}_{\mathrm{jt}}=\mathrm{X}_{\mathrm{jt}} / \mathrm{B}_{\mathrm{jt}-1}>0$, for $\mathrm{t}$ and $\mathrm{t}-1$. Siddique and Sweeney (2006) find empirically that firms with negative book behave differently from firms with positive book.

${ }^{8}$ Sometimes these channels are formulated as the changes in price $\Delta \mathrm{P}_{\mathrm{jt}}$ and earnings $\Delta \mathrm{X}_{\mathrm{jt}}$ and the un-logged level $\mathrm{X}_{\mathrm{jt}}$. The variables are then typically normalized by $\mathrm{P}_{\mathrm{jt}-1}$ to give $\Delta \mathrm{P}_{\mathrm{jt}} / \mathrm{P}_{\mathrm{jt}-1}, \Delta \mathrm{X}_{\mathrm{jt}} / \mathrm{P}_{\mathrm{jt}-1}, \mathrm{X}_{\mathrm{jt}} / \mathrm{P}_{\mathrm{jt}-1}$; Easton and Harris (1991) use this approach. This paper's specifications avoid problems that arise from dividing variables by the same (lagged) integrated variable, $\mathrm{P}_{\mathrm{jt}}$. This paper focus on $\Delta \mathrm{ln} \mathrm{P}_{\mathrm{jt}}$, but Easton and Harris include dividends.

${ }^{9}$ Year effects are captured by allowing differing intercepts for the two years.

${ }^{10}$ If both $\Delta \ln X_{\mathrm{j}, \mathrm{t}}$ and $\ln \mathrm{X}_{\mathrm{j}, \mathrm{t}}$ are included in an OLS regression, the slope on $\ln \mathrm{X}_{\mathrm{j}, \mathrm{t}}$ is unstable and often insignificant. For 1996 data, the slope and $t$-value for $\Delta \ln X_{j, 1996}$ are virtually unchanged, but $\ln X_{j, 1996}$ has the slope (t-value) of -0.019061 (1.911287), a sign reversal. For 1995 data, the slope and $t$-value for $\Delta \ln X_{j, 1995}$ are virtually unchanged, but $\ln X_{j, 1995}$ has a sign reversal and a t-value of only -0.141844 .
} 
Estimates of $\mathbf{G}$ : The $\mathrm{R}^{2}$ in a regression of $\ln \mathrm{X}_{\mathrm{j}, 1996}$ on $\Delta \ln X_{j, 1996}$ is 0.087517 , or the cross-section variability of $\Delta \ln X_{j, 1996}\left(\equiv \ln X_{j, 1996}-\ln X_{j, 1995}\right)$ explains about $9 \%$ of the variability in $\ln \mathrm{X}_{\mathrm{j}, 1996}$. For $\ln \mathrm{X}_{\mathrm{j}, 1995}$ regressed on $\Delta \ln \mathrm{X}_{\mathrm{j}, 1995}$, the $\mathrm{R}^{2}$ is 0.091374 . These $\mathrm{R}^{2} \mathrm{~s}$ suggest $\mathrm{G} \approx 11$ years $(1 / 0.087517=$ 11.4264 and $1 / 0.091374=10.9440)$. Thus, in Table 2 the results for $\mathrm{G}=10$ appear more appropriate.

\section{The Integrated Regressor as a Proxy Variable for an Omitted Categorical REGRESSOR: NEW DEVELOPMENTS}

Consider the case where the true relationship is between an $\mathrm{I}(0)$ variable and a categorical variable that can take only a limited number of values. For example, in an event study discussed below, returns may have a larger mean for the small firms than for large firms, where small (large) firms are those in the lower (upper) half of the size distribution, but within each half returns are uncorrelated with size. Many researchers, however, regress the rate of return on $(\log )$ size. If the researcher uses the I(1) variable size as a regressor, its true coefficient is necessarily zero. If returns depend on the categorical variable in size, then in a regression where the categorical variable is omitted and size is a proxy for it, the expectation of the estimated slope of size is negative, and as the number of firms in the cross section grows large the plim of the slope's t-value diverges to negative infinity. In such a case, the solution is to use the correct categorical variable, "small" versus "large," Similar problems arise in studies where the categorical variable is say "newer" versus "older" firms but the researcher uses a time trend or trend-like explanatory variable such as firm "age." In an analysis consistent with the above, firms are analytically and empirically divided into a limited number of categories based on log size (or on age or other trend-type variables). For example, the researcher believe that firms fall into five size categories ranging from low to high, along with say five categories of the book-tomarket ratio. In this view, movements of the firm's log size from one category to another affect its 
conditional rate of return, but movements within the category do not. Without loss of generality, suppose there are two categories, and let the conditional relationship be

$$
\mathrm{y}_{\mathrm{jt}}=\alpha+\alpha_{\mathrm{sm}} \mathrm{D}_{\mathrm{jt}}
$$

where $\mathrm{y}_{\mathrm{jt}}$ can be taken as the firm's rate of return, $\mathrm{x}_{\mathrm{jt}-1}$ is $\log$ size (or another stochastic or deterministic trend-type variable), the firms are divided into halves based on $\mathrm{x}_{\mathrm{jt}-1}$ relative to the median value $\mathrm{x}_{m \mathrm{t}-1}$, with $\mathrm{D}_{\mathrm{jt}}=1$ if $\mathrm{x}_{\mathrm{jt}-1} \leq \mathrm{x}_{\mathrm{mt}-1}$ and $\mathrm{D}_{\mathrm{jt}}=0$ if $\mathrm{x}_{\mathrm{jt}-1}>\mathrm{x}_{\mathrm{mt}-1}$, and for specificity $\alpha_{\mathrm{sm}}>\alpha>$ $0 .{ }^{11}$ For trend-like variables such as firm age, a conditional relationship similar to (5) is consistent with the category approach. ${ }^{12}$ In either case, let the error be $\mathrm{u}_{\mathrm{jt}} \sim$ iid $\left(0, \sigma_{\mathrm{u}}^{2}\right), \mathrm{E}\left(\mathrm{D}_{\mathrm{jt}} \mathrm{u}_{\mathrm{jt}}\right)=0$.

Instead of focusing on the true categorical relationship in (5), suppose the researcher believes the firm's predetermined log size [or age] continuously and linearly affects its conditional rate of return. The appropriate regression specification, associated with the true DGP (5), is

$$
y_{j t}=a+a_{s m} D_{j t}+z_{j t}
$$

Nevertheless, in the OLS regression,

$$
y_{j t}=a+g_{j t-1}+z_{j t} \quad j=1, \ldots, N, t=T^{\prime}, \ldots, T
$$

generally plim $\hat{\mathrm{g}} \neq 0$ and in a large cross section is likely to be significant. Let $\mathrm{x}_{\mathrm{jt}-1}=\left[\Sigma^{\mathrm{T}+\mathrm{t}-1} \mathrm{~T}^{\prime}+\mathrm{h}=\mathrm{T}^{\prime}+1\right.$ $\left.\Delta \mathrm{x}_{\mathrm{j}, \mathrm{T}^{+}+\mathrm{h}}\right] \sim \mathrm{G}^{1 / 2} \sigma_{\Delta \mathrm{x}}$ iid $\mathrm{N}(0,1)$. Intuitively, $\mathrm{y}_{\mathrm{jt}}$ is unrelated to $\mathrm{x}_{\mathrm{jt}-1}$ within each category, $\mathrm{x}_{\mathrm{jt}}<\mathrm{x}_{\mathrm{mt}}$ and $\mathrm{x}_{\mathrm{jt}}$ $\geq \mathrm{x}_{\mathrm{mt}}$. But $\mathrm{x}_{\mathrm{jt}}$ is correlated with the category into which a firm falls, and thus in regression (8) $\hat{\mathrm{g}}$ is likely to show a spurious continuous relationship between $\mathrm{y}_{\mathrm{jt}}$ and $\mathrm{x}_{\mathrm{jt}-1}$.

THEOREM 3 (included for completeness): For the conditional expectation in (5) and the error $u_{j t}$, in the OLS regression $R_{j t}=a+a_{s m} D_{j t}+z_{j t}$, plim $a=\alpha$, plim $a_{s m}=\alpha_{s m}$ and the $\hat{a}, \hat{a}_{s m}$ are asymptotically distributed normal around their true values.

In the OLS regression, the slope estimate is 


$$
\hat{\mathrm{g}}=\left[\alpha_{\mathrm{sm}} \operatorname{cov}\left(\mathrm{D}_{\mathrm{jt}}, \mathrm{x}_{\mathrm{jt}}\right) / \operatorname{var}\left(\mathrm{x}_{\mathrm{jt}}\right)\right]+\left[\operatorname{cov}\left(\mathrm{u}_{\mathrm{jt}}, \mathrm{x}_{\mathrm{jt}}\right) / \operatorname{var}\left(\mathrm{x}_{\mathrm{jt}}\right)\right]
$$

Let $\hat{\mathrm{m}}_{\mathrm{sm}}, \hat{\mathrm{m}}_{\mathrm{la}}$ denote are the means of the halves of the sample with small and large values of $\mathrm{x}_{\mathrm{jt}}$ relative to the median $\mathrm{x}_{\mathrm{mt}}$, and let $\mathrm{m}_{\mathrm{sm}}=-\mathrm{m}_{\mathrm{la}}<0$ denote the means' asymptotic values.

THEOREM 4: $p l i m \hat{g}=\alpha_{s m} m_{s m} / G \sigma_{\Delta x}^{2}=-\left(0.675 G^{1 / 2} \sigma_{\Delta x}\right) \alpha_{s m} / G \sigma_{\Delta x}^{2}=-0.675 \alpha_{s m} / G^{1 / 2} \sigma_{\Delta x}<$ 0. As $N \rightarrow \infty, \hat{g} \rightarrow^{d} \alpha_{s m} m_{s m} / G \sigma_{\Delta x}^{2}+(N G)^{-1 / 2}\left(\sigma_{u} / \sigma_{\Delta x}\right) N_{\Delta, x}(0,1)=\left[-0.675 \alpha_{s m} / G^{1 / 2} \sigma_{\Delta x}\right]+(N$ $G)^{-1 / 2}\left(\sigma_{u} / \sigma_{\Delta x}\right) N_{\Delta, x}(0,1)$. From $\alpha_{s m}>0, \hat{g}$ is asymptotically normal around its mean, $-0.675 \alpha_{s m} /$ $G^{1 / 2} \sigma_{\Delta x}<0$. Moreover, plim $t_{g}=-0.675 N^{1 / 2}\left(\alpha_{s m} / \sigma_{u}\right)<0 ;$ as $N^{1 / 2} \rightarrow \infty$, then plim $t_{g}$ diverges to negative infinity. As $N \rightarrow \infty$, then $[V(\hat{g})]^{1 / 2} \rightarrow(N G)^{-1 / 2}\left(\sigma_{u} / \sigma_{\Delta x}\right)$ and $t_{g} \rightarrow-0.675 N^{1 / 2}\left(\alpha_{s m} / \sigma_{u}\right)+$ $N_{\Delta x, x}(0,1)$.

Interpretation: As in the continuous-variable case, plim $\hat{g}$ depends inversely on $\mathrm{G}$; plim $\mathrm{t}_{\mathrm{g}}$ does not depend on $\mathrm{G}$ in this categorical-variable case, but $\mathrm{t}_{\mathrm{g}}$ does in the continuous case.

The data must contain a true relationship between the $\mathrm{I}(0)$ dependent variable and an unincluded $\mathrm{I}(0)$ variable for the unbalanced regression to show a spurious relationship between the $\mathrm{I}(0)$ dependent variable and the included I(1) variable that shows sample correlation with the unincluded variable. If small and large firms have the same mean, $\alpha$, then $\alpha_{\mathrm{sm}}=0$ and plim $\hat{\mathrm{g}}=\left[\alpha_{\mathrm{sm}} \mathrm{m}_{\mathrm{sm}} / \mathrm{G}\right.$ $\left.\sigma^{2}{ }_{\mathrm{x}}\right]=0$. If $\mathrm{D}_{\mathrm{jt}}, \mathrm{x}_{\mathrm{jt}}$ are uncorrelated, as $\mathrm{N}$ grows large $\operatorname{cov}\left(\mathrm{D}_{\mathrm{jt}}, \mathrm{x}_{\mathrm{jt}}\right) \rightarrow^{\mathrm{p}} 0$ and thus plim $\hat{\mathrm{g}}=0$.

A number of empirical puzzles, regarding instability of results and non-linear relationships, are likely to arise if the researcher uses the misspecification in (7) rather then the appropriate specification in (6); section 5 presents illustrative simulation results.

Remedies for the Misspecification: The remedy for the misspecification in (7) is to use the sizebased categorical specification in (6). Using $\Delta \mathrm{x}_{\mathrm{jt}-1}$ is not the remedy. Let the researcher consider the

\footnotetext{
${ }^{11}$ In the DGP $y_{j t}=\alpha+\alpha_{s m} D_{j t}+u_{j t}$, the categorical variable $\alpha+\alpha_{s m} D_{j t}$ is stationary but may well not be ergodic. The mean across firms is $\left[\alpha+(1 / 2) \alpha_{\mathrm{sm}}\right]$. If the size-change process $\Delta \mathrm{x}_{\mathrm{jt}}$ and the error $\mathrm{u}_{\mathrm{jt}}$ are highly likely to leave the firm in the smaller half over time, the firm's mean time-series return is likely $\left[\alpha+\alpha_{\mathrm{sm}}\right]>\left[\alpha+(1 / 2) \alpha_{\mathrm{sm}}\right]$.
} 
regression

$$
\mathrm{y}_{\mathrm{jt}}=\mathrm{a}+\mathrm{g} \Delta \mathrm{x}_{\mathrm{jt}}+\mathrm{z}_{\mathrm{jt}}
$$

Both (7) and (8) are misspecifications, but generally (7) gives stronger results than (8), tempting the researcher to use the unbalanced regression $(7) .{ }^{14}$

Use of a regressor in which $\mathrm{x}_{\mathrm{jt}}$ enters in ratio form is generally inappropriate. First, in this case, the true conditional expectation in (5) includes a categorical, discrete variable in $\mathrm{x}_{\mathrm{jt}}$, not a continuous variable in $\mathrm{x}_{\mathrm{jt}}$. Second, the ratio may be $\mathrm{I}(1)$. For example, in $\log$ terms the ratio of size to its median is $\mathrm{x}_{\mathrm{jt}}-\mathrm{x}_{\mathrm{mt}}$; unless $\mathrm{x}_{\mathrm{jt}}$ and $\mathrm{x}_{\mathrm{mt}}$ are cointegrated, then $\left(\mathrm{x}_{\mathrm{jt}}-\mathrm{x}_{\mathrm{mt}}\right) \sim \mathrm{I}(1)$. This is related to the issue of ROE $\sim \mathrm{I}(1)$. Let earnings $\mathrm{X}_{\mathrm{t}} \sim \mathrm{I}(1)$ and book $\mathrm{B}_{\mathrm{t}} \sim \mathrm{I}(1)$ be related through $\mathrm{X}_{\mathrm{t}}=\gamma \mathrm{B}_{\mathrm{t}-1}+\mathrm{B}_{\mathrm{t}-1} \varepsilon_{\mathrm{t}}$, where $\gamma$ $>0$ is a parameter and $\varepsilon_{t}$ an error with effects proportional to $B_{t-1}$. Then, $\operatorname{ROE}_{t}=X_{t} / B_{t-1}=\gamma+\varepsilon_{t}$, and $\mathrm{ROE}_{\mathrm{t}} \sim[\mathrm{I}(0), \mathrm{I}(1)]$ as $\varepsilon_{\mathrm{t}} \sim[\mathrm{I}(0), \mathrm{I}(1)]$. Failure to reject the null that $\mathrm{ROE} \sim \mathrm{I}(1)$ is equivalent to failure to reject the null that $\mathrm{X}_{\mathrm{t}}$ and $\mathrm{B}_{\mathrm{t}}$ are not cointegrated. ${ }^{15}$

Does Theory Specify Continuous Measures? The researcher may acknowledge the problem of regressing $\mathrm{y}_{\mathrm{jt}} \sim \mathrm{I}(0)$ on $\mathrm{x}_{\mathrm{jt}} \sim \mathrm{I}(1)$ but still insist that theory specifies size as the explanatory variable. Often, such arguments confuse continuous with categorical measures of $\mathrm{x}_{\mathrm{jt}}$. As an example, the null "Size does not affect the rate of return" and the alternative "Size negatively affects the rate of return"

1215 of the 42 papers discussed in section 1 include either time-trends or trend-like variables such as age of firm.

${ }^{13}$ Intuitively, $\mathrm{y}_{\mathrm{jt}}$ depends in part on $\mathrm{D}_{\mathrm{jt}} \alpha_{\mathrm{sm}}$; because $\mathrm{x}_{\mathrm{jt}-1}=\sum \Delta \mathrm{x}_{\mathrm{jt}-\mathrm{h}}$ and $\mathrm{D}_{\mathrm{jt}}$ depends on $\mathrm{x}_{\mathrm{jt}-1}$, likely $\Delta \mathrm{x}_{\mathrm{jt}-1}$ shows a weak correlation with $\mathrm{D}_{\mathrm{jt}}$ and thus may weakly enter (10).

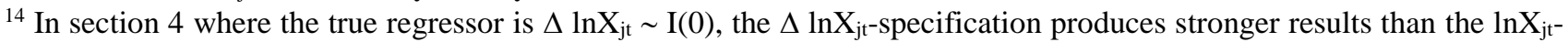
specification. In this section the $\ln \mathrm{X}_{\mathrm{jt}}$-specification produces stronger results than the $\Delta \ln \mathrm{X}_{\mathrm{jt}}$-specification: the true explanatory variable here is categorical, neither $\Delta \mathrm{x}_{\mathrm{jt}}$ nor $\mathrm{x}_{\mathrm{jt}}$.

${ }^{15}$ Researchers often assume that financial and accounting ratios are $\mathrm{I}(0)$. For example, some deflate an I(1) variable by another I(1) variable to "remove trends." When researchers apply standard tests of the unit-root null to ratios, sometimes the data can reject the null but often they cannot. Generally, it appears wiser to treat a ratio as I(1) if the data in the sample being examined cannot reject the unit-root null. Often, however, data in panels have few time-series observations, and of course a cross section contains only a single observation for each element of the cross section. Thus, unit-root tests on such panels may have little power. But, for such cases, consider the DGPs for the ratios, and compare results for a regression with $\Delta \mathrm{x}_{\mathrm{jt}}$ with results for a regression with $\mathrm{x}_{\mathrm{jt}}$. If the DGP generates $\mathrm{x}_{\mathrm{jt}} \sim \mathrm{I}(1)$, and the true relationship is between $\mathrm{y}_{\mathrm{jt}}$ and $\Delta \mathrm{x}_{\mathrm{j} t}$, then the text's discussion implies the researcher will find stronger results using the specification with $\Delta \mathrm{x}_{\mathrm{jt}}$ rather than $\mathrm{x}_{\mathrm{jt}}$. It the DGP generates $\mathrm{x}_{\mathrm{jt}} \sim \mathrm{I}(0)$, and the true relationship is between $\mathrm{y}_{\mathrm{jt}}$ and $\mathrm{x}_{\mathrm{jt}}$, the specification with $\mathrm{x}_{\mathrm{jt}}$ will yield stronger results than $\Delta \mathrm{x}_{\mathrm{jt}}$. Thus, in the case of few time-series observations on $\mathrm{x}_{\mathrm{jt}}$, trying specifications with both $\Delta \mathrm{x}_{\mathrm{jt}}$ and $\mathrm{x}_{\mathrm{jt}}$ should allow the researcher to infer the true relationship as well as the order of integration of $\mathrm{x}_{\mathrm{jt}}$. 
do not imply the continuous test equation (8), but are consistent with the categorical-variable specification (7). If the relationship to size is continuous (and monotonic), doubling all firms' sizes reduces all expected $\mathrm{y}_{\mathrm{jt}}$; if categorical, doubling all firms' size may leave all expected rates of return unchanged, but with $\alpha_{s m}>\alpha$ before and after the doubling.

\section{Simulation Study with a Categorical Variable}

To explore the results in section 4, consider a simulation study of the effect of size on returns. Figure 1 illustrates a simulation for 1,000 firms. The errors are $\mathrm{u}_{\mathrm{jt}} \sim \sigma_{\mathrm{u}}$ iid $\mathrm{N}(0,1)$, size is $\mathrm{S}_{\mathrm{jt}-1}=\left[\Sigma^{\mathrm{T}^{\prime}+\mathrm{t}-}\right.$

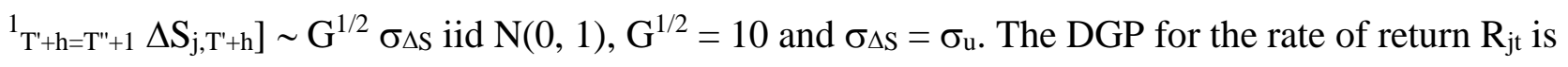

$$
R_{j t}=D_{j t} \alpha_{s m}+\left(1-D_{j t}\right) \alpha_{l a}+u_{j t}=D_{j t} 0.20 \times \sigma_{u}-\left(1-D_{j t}\right) 0.20 \times \sigma_{u}+u_{j t}
$$

where $\alpha_{\mathrm{sm}}=0.20 \sigma_{\mathrm{u}}, \alpha_{\mathrm{la}}=-0.20 \sigma_{\mathrm{u}}$, and the dummy variable is $\mathrm{D}_{\mathrm{jt}}=\{1,0\}$ as $\left\{\mathrm{S}_{\mathrm{jt}-1}<\mathrm{S}_{\mathrm{mt}-1}, \mathrm{~S}_{\mathrm{jt}-1} \geq\right.$ $\left.\mathrm{S}_{\mathrm{mt}-1}\right\}$ where the median size is $\mathrm{S}_{\boldsymbol{m t}-1}$. Table 4 shows that for the misspecification

$$
R_{j t}=a+g S_{j t-1}+z_{j t}
$$

the slope (t-value) [probability] are $-0.016406(-4.812320)[0.0000]$, and $\mathrm{R}^{2}=0.022679$.

I(1) Regressors and Empirical Puzzles: Researchers often report puzzling instability and nonlinearities over sub-sets of a cross section or over differing data sets. Note that if the true model is the qualitative model (5), then the regression in (10) is likely to show instabilities and non-linearities over subsets. Using the simulation data shown in Figure 1, Table 4 presents regression results that illustrate some puzzles. In a regression over the whole sample, $\hat{\mathrm{g}}<0$ in the linear specification in (10), as reported above; the linear specification seems to "work." If the researcher examines only firms in the same half of the size distribution, the detected relationship tends to vanish, making $\hat{\mathrm{g}}$ appear to be unstable and insignificant. For the smallest 500 firms the results are 0.000971 
(0.121879) [0.9030], and for the largest 500 are $-0.003759(-0.488689)$ [0.6253]. This instability arises from using the misspecified estimating equation (10).

Spurious Threshold and Satiation Effects: The researcher might fit a piece-wise linear relationship over three sub-samples, one with the 250 smallest firms, one with the 250 largest firms, and one with a mixture of small and large firms. (Alternatively, the researcher may fit $\mathrm{R}_{\mathrm{jt}}$ as a nonlinear function of $\mathrm{S}_{\mathrm{jt}-1}$, with continuous derivatives, e.g., a cubic.) For example, in Table 4 , for the middle 500 firms in a linear regression the results are $-0.041741(-3.043186)$ [0.0025], but for the 250 smallest are $-0.010431(-0.815052)[0.4158]$ and for the 250 largest $-0.006195(-0.463631)$ [0.6433]. These piece-wise linear results in Table 4 might be interpreted to show a "threshold" size before the relationship applies, and a "satiation" point beyond which increases in size have no effect. The creative researcher may provide explanations for threshold and satiation effects - effects that are spurious and arise because of using the unbalanced regression (10).

Comparative Statics: Using the data in the simulation illustrates a number of results. The initial data series, $\mathrm{R}_{\mathrm{jt}}, \mathrm{S}_{\mathrm{jt}-1}$ were generated as $\alpha_{\mathrm{sm}}=-\alpha_{\mathrm{la}}=0.20, \sigma_{\mathrm{u}}=1, \mathrm{G}^{1 / 2}=10, \mathrm{u}_{\mathrm{jt}} \sim$ iid $\sigma_{\mathrm{u}} \mathrm{N}_{\mathrm{u}}(0,1)$ and $\mathrm{S}_{\mathrm{jt}-1} \sim$ iid $\mathrm{G}^{1 / 2} \sigma_{\mathrm{u}} \mathrm{N}_{\mathrm{x}}(0,1)$. By saving the set of realizations $\left\{\mathrm{u}_{\mathrm{jt}}, \mathrm{S}_{\mathrm{jt}-1}\right\}$, the precise effects of parametric changes can be found. Panel B shows results for three cases. (i) Double the initial series $R_{1 j t}, S_{1 j t-1}$ to give the series $R_{2 j t}, S_{2 j t-1}$ t this leaves $\hat{g}$ unaffected. (ii) Double $S_{1 \mathrm{jt}-1}$ to give $S_{2 \mathrm{jt}-1}$, but hold constant the $R_{1 j}$ : the slope and t-value are approximately halved. (iii) Keep the $S_{1 j t}$ constant but double $\mathrm{R}_{1 \mathrm{jt}}$ to $\mathrm{R}_{3 \mathrm{jt}}$ : the slope and $\mathrm{t}-\mathrm{value}$ double.

Monthly versus Annual Data: Whether data are monthly or say annual does not affect results. Let all data be in logs or differences of logs. Monthly and annual measures for variance and firm life are $\sigma_{u, m t h}^{2}=\sigma_{u, y r}^{2} / 12, G_{m t h}=12 G_{y r}$, and hence $N\left(0, G_{y r} \sigma_{u, y r}^{2}\right)=N\left(0, G_{m t h} \sigma_{u, m t h}^{2}\right)$. In (7) implicitly $\alpha_{\mathrm{sm}, \mathrm{mth}}=(12)^{-1 / 2} \alpha_{\mathrm{sm}, \mathrm{yr}}$, giving $\mathrm{ER}_{\mathrm{jt}, \mathrm{mth}} / \alpha_{\mathrm{sm}, \mathrm{mth}}=\mathrm{ER}_{\mathrm{jt}, \mathrm{yr}} / \alpha_{\mathrm{sm}, \mathrm{yr}}$. 


\section{SuMMARY AND CONCLUSIONS}

Virtually no cross-section finance study reports the order of integration of its variables, nor do those panel studies where the number of time periods $\mathrm{T}$ is small and the cross-section $\mathrm{N}$ is large. This paper shows that severe problems can arise in cross-section or panel studies that regress $\mathrm{I}(0)$ dependent variables on I(1) explanatory variables; these "unbalanced regression" problems are different from those in unbalanced time-series regressions, but are comparably severe. This paper also provides step-by-step procedures to deal with unbalanced regressions: It discusses how to avoid problems, to diagnose problems and to remedy problems.

Many regressors in cross-section finance studies appear to be I(1), as Appendix II shows in a brief survey focused on articles within 2005 in the most prestigious finance and econometrics Journals. For example, firm size is likely I(1) whether measured by market or accounting data. Further, many ratios may be I(1), as suggested by the finding that the return on equity and the rate of return on invested capital are I(1), and many micro-structure variables may be I(1), as suggested by the finding that volume for Dow Jones 30 stocks cannot reject the unit root null.

This paper focuses on cases where the $\mathrm{I}(0)$ dependent variable is importantly associated with an $\mathrm{I}(0)$ explanatory variable. The researcher, however, omits the true $\mathrm{I}(0)$ regressor and as a proxy for it uses an I(1) explanatory variable that shows sample correlation with the true $\mathrm{I}(0)$ regressor. This paper explores in detail theoretical results for this case, whether the true $\mathrm{I}(0)$ variable is continuous (i.e., can take on any real value) like the change in earnings or is categorical (i.e., can represent only a limited number states) like large versus small firms, and also provides empirical and simulation examples. If the cross section is large, the researcher is likely to find a spurious relationship between the $\mathrm{I}(0)$ dependent variable and the $\mathrm{I}(1)$ regressor.

In these cross-section unbalanced regressions, the researcher may find no relationship, abandon this path and thus fail to uncover the true $\mathrm{I}(0)$ explanatory variable. Or, the regression may show a 
small but statistically significant relationship. This estimated relationship is spurious, but arises because the cross-section is large. The researcher may accept the spurious relationship with the I(1) regressor, and fail to explore farther to find the true relationship with an $\mathrm{I}(0)$ regressor that shows sample correlation with the I(1) variable. In an unbalanced regression, a significant slope on an I(1) regressor is a diagnostic, however: It strongly suggests the data contain a valid, stronger relationship to an $\mathrm{I}(0)$ variable.

In designing a cross-section or panel study, unit-root tests provide guidance on how to treat variables econometrically, rather than "proving" variables are I(1) or not (Campbell and Perron, 1991). The researcher may have cogent arguments that a variable is $\mathrm{I}(0)$, but if the data cannot reject the unit-root null, it is often sound econometric practice is to treat the variable as I(1).

The researcher may argue $\mathrm{T}$ for his/her data is too small to allow unit-root tests; some approaches, however, require modest T, e.g., see Breitling and Meyer (1994), Levin and Lin (1991) and Im, Pesaran and Shin (2003). Further, the literature provides much time-series evidence on some of the variables used in cross section studies, for example, firm size, assets, etc. In addition, in doubtful cases the researcher might replace the suspect variable with a related stationary variable, for example, the first difference or a related categorical variable.

This paper's discussion — of unbalanced-regression problems and their solutions-applies directly to the many finance studies that use a single cross-section or use panel techniques where $\mathrm{N}$ is large but T is small (Wooldridge, 2002; Hsaio, 2003; Mátyás and Sevestre, 2006; Baltagi, 2005). Most often these studies take $\mathrm{T}$ as fixed and asymptotic results depend on $\mathrm{N}$ growing large.

When both $\mathrm{T}$ and $\mathrm{N}$ are large, unbalanced-regression problems arise that are a combination of the cross-section problems discussed here and the more familiar time-series problems, but this paper does not analyze such problems. The large-N, large-T case seldom applies to corporate finance panels where typically (a) $\mathrm{N}$ is large $\mathrm{N}$ and $\mathrm{T}$ is small, and (b) the researcher takes $\mathrm{T}$ as fixed and 
relies on asymptotics from $\mathrm{N}$ growing large. In contrast, as Phillips and Moon (1999, p. 1059) point out, results for panels with non-stationary variables generally require that the rate condition $\mathrm{N} / \mathrm{T} \rightarrow$ 0 hold, or "the limit distribution theory ... is most likely to be useful in practice when $\mathrm{N}$ is moderate and T is large." (see also surveys by Baltagi and Kao, 2000 and Phillips and Moon, 2000). 


\section{REFERENCES}

Bai, J. and Ng, S., "A PANIC attack on unit roots and cointegration," Econometrica 72 (2004), $1127-1177$.

Baltagi, Badi H. Econometric Analysis of Panel Data. $3^{\text {rd }}$ ed. New York: Wiley, 2005.

Baltagi, Badi H., and Chihwa Kao, "Nonstationary Panels, Cointegration in Panels and Dynamic Panels: A Survey," Advances in Econometrics 15 (2000), 7-51.

Banerjee, Anindya, Juan Dolado, John W. Galbraith and David F. Hendry. Co-integration, ErrorCorrection, and the Econometric Analysis of Non-Stationary Data. Oxford: OUP, 1993.

Campbell, John Y., and Pierre Perron, "Pitfalls and Opportunities: What Macroeconomists Should Know about Unit Roots," in O.J. Blanchard and S. Fischer (eds.) NBER Macroeconomics Annual 6 (1991), MIT Press, Cambridge, MA.

Demetrescu, M. and Hanck, C.. "Unit root testing in heteroscedastic panels using the Cauchy estimator," Journal of Business and Economic Statistics 30 (2012), 256-264.

Easton, Peter D., and Trevor S. Harris, "Earnings as an Explanatory Variable for Returns," Journal of Accounting Research 29 (1991), pp. 19-36.

Hanck, C. and Czudaj, R.,. "Nonstationary-volatility robust panel unit root tests and the great moderation," Advances in Statistical Analysis 99 (2015), 161-187.

Hsiao, Cheng. Analysis of Panel Data. $2^{\text {nd }}$ ed. Cambridge: Cambridge University Press, 2003.

Im, Kyong So, M. Hashem Pesaran, and Yougcheol Shin, "Testing for Unit Roots in Heterogeneous Panels," Journal of Econometrics 115 (2003), 53-74.

Levin, Andrew, and Chien-Fu Lin. Unit Root Tests in Panel Data: Asymptotic and Finite Sample Results. San Diego: Working Paper, University of California, San Diego, 1992.

Levin, Andrew, Chien-Fu Lin and Chia-Shang James Chu, "Unit Root Tests in Panel Data: Asymptotic and Finite Sample Properties," Journal of Econometrics 108 (2002), 1-24.

Mátyás, László, and Patrick Sevestre, Eds. The Econometrics of Panel Data. A Handbook of the Theory with Applications. $3^{\text {rd }}$ ed. Kluwer, 2006.

Ohlson, James A., and Pervin K. Shroff, "Changes versus Levels in Earnings as Explanatory Variables for Returns: Some Theoretical Considerations," Journal of Accounting Research 30 (1992), pp. 210-226.

Phillips, Peter C. B., and Hyungsik R. Moon, "Linear Regression Limit Theory for Nonstationary Panel Data," Econometrica 67 (1999), 1057-1111. 
Phillips, Peter C. B., and Hyungsik R. Moon, "Nonstationary Panel Data Analysis: An Overview of Some Recent Developments," Econometric Reviews 19 (2000), 263-286.

Siddique, Akhtar, and Richard J. Sweeney. Dynamics in Valuation-Model Profit Rates: Unit-Root Tests and Their Implications. Washington, D.C.: Working Paper, The McDonough School of Business, Georgetown University, 2006.

Wooldridge, Jeffrey M. Econometric Analysis of Cross Section and Panel Data. Boston, MA: MIT Press, 2002. 


\section{Table 1. Representative Articles Using Cross-Section, Panel Methods}

\section{Independent Variable}

Size, Price, Scale Measures

log of firm size (market value)

$\log$ (market capitalization)

$\log$ (total assets)

$\log$ (total assets)

$\log$ (total assets)

$\log$ (fund's total net assets)

$\log ($ GDP $)$

average of log proceeds

$\log$ of SEO proceeds

Total assets

$\log$ total assets

GDP per capita

GDP per capita

GDP per capita

GDP per capita

GDP per capita

Stock market turnover

Principal amount

$\log$ of amount of bond issue

$\log$ IPO filing size

Demand per bidder in auction

Aggregate demand in auction

Auction size

Value of shares owned

Total pay

Free cash flows

Total assets

CEO salary

log sales

log sales

log sales

\section{Author(s)}

Datta, Iskandar-Datta, Raman

Fernando, Gatchev, Spindt

Faccio and Masulis

Molina

Malmendier and Tate

Cooper, Gulen and Rau

Beck, et al.

Keloharju, Nyborg, Rydqvist

Keloharju, Nyborg, Rydqvist

Haslem

Jenter

Beck, et al.

Faccio and Masulis

Chan, Covrig and $\mathrm{Ng}$

Gelos and Wei

Stulz

Stulz

Longstaff, Mithal, Neis

Yasuda

Lungqvist and Wilhelm

Keloharju, Nyborg, Rydqvist

Keloharju, Nyborg, Rydqvist

Keloharju, Nyborg, Rydqvist

Jenter

Jenter

Haslem

Haslem

Haslem

Perry and Peyer

Grinstein and Michaely

Beck, et al.

\section{Topic/Short Title}

Managerial Stock Own.

Underwriting

Payment method, M\&A

Firms' leverage

CEO overconfidence

Mutual-fund names

Firm size and growth

Underpricing in auctions

Underpricing in auctions

Managerial opportunism

Managers' portfolios

Firm size and growth

Payment method, M\&A

Domestic, foreign biases

Transparency

Financial globalization

Financial globalization

Corporate yield structure

Bank relationships

Prospect Theory, IPOs

Underpricing in auctions

Underpricing in auctions

Underpricing in auctions

Managers' portfolios

Managers' portfolios

Managerial opportunism

Managerial opportunism

Managerial opportunism

Board seat accumulation

Institutional holdings

Firm size and growth

\section{Dependent Variable}

Percentage of debt maturing in 3 years measure of rep., lead SEO underwriter Per. of cash financing, tobit model $\mathrm{S} \& \mathrm{P}$ ratings

Capex relative to capital stock

$0-1$ variable as firm changes name

3 -yr percentage change in sales percentages of face value percentages of face value cum. ab. returns, given window sizes Net pur. of company stock rel. to past 3 -yr percentage change in sales Per. of cash financing, tobit model Domestic bias in share holdings residuals from an ICAPM regression percent of portfolio family-held percent of portfolio family-held

Av. non-default component of spread Underwriting fees (gross spread) zero-one variable percentages of face value percentages of face value percentages of face value Net pur. of company stock rel. to past Net pur. of company stock rel. to past cum. ab. returns, given window sizes cum. ab. returns, given window sizes cum. ab. returns, given window sizes cum. abnormal return, days -1 to +1 chg. in inst. holdings/rel. to total 3 -yr percentage change in sales 


\section{Independent Variable}

Size, Price, Scale Measures (cont.)

turnover (maximum during quarter)

$\log ($ issue proceeds)

1/(principal amt. of SEO offering)

Value of SEO issuance by all firms

Value of loan facility

$\log$ (principal amount of offering)

Flow to mutual fund

Loan size

$\log$ (no. of stocks in $\mathrm{HH}$ port.)

$\log$ (value of stocks, HH port.)

$\log$ (household income)

$\log$ (market value)

$\log$ (number of employees)

$\log$ (expected proceeds of IPO)

Proceeds

Transaction size (IPO)

$\log$ (float)

volume

\section{Ratios}

ROA

No. $r$ of shares traded/benchmark

Market share of sales

Market share of sales

Market to book

Market to book

Market to book

Net working capital/total assets

(CAPEX+R\&D)/(total assets)

(cash+tradable secs, $) /($ total assets)

\section{Author(s)}

Leary and Roberts

Fang

Drucker and Puri

Drucker and Puri

Drucker and Puri

Drucker and Puri

Cooper, Gulen and Rau

Degryse and Ongena

Ivković and Weisbenner

Ivković and Weisbenner

Ivković and Weisbenner

Ivković and Weisbenner

Ivković and Weisbenner

Corwin and Schultz

Corwin and Schultz

Derrien

Derrien

Derrien

Perry and Peyer

Faccio and Masulis

Faccio and Masulis

Leary and Roberts

Faccio and Masulis

Grinstein and Michaely

Ivković and Weisbenner

Faccio and Masulis

Faccio and Masulis

Faccio and Masulis
Topic/Short Title

Capital structure

Investment bank reps.

Lending, underwriting

Lending, underwriting

Lending, underwriting

Lending, underwriting

Mutual-fund names

Distance, lending

Local information

Local information

Local information

Local information

Local information

IPO syndicates

IPO syndicates

IPO pricing, hot markets

IPO pricing, hot markets

IPO pricing, hot markets

Board seat accumulation Payment method, M\&A Payment method, M\&A Capital structure

Payment method, M\&A Institutional holdings

Local information

Payment method, M\&A

Payment method, M\&A

Payment method, M\&A

\section{Dependent Variable}

Changes in leverage, or probability of four discrete outcomes 0-1 variables in probit regression, or gross spread on issue Underwriters' spreads (percentage), or 0 -1 variables "

0-1 variable as firm changes name loan rate until next revision Av. miles to portfolio stock Av. miles to portfolio stock Av. miles to portfolio stock Av. miles to portfolio stock Av. miles to portfolio stock zero-one in probit regression zero-one in probit regression oversubscription (a ratio) oversubscription (a ratio) oversubscription (a ratio)

cum. abnormal return, days -1 to +1 Per. of cash financing, tobit model Per. of cash financing, tobit model Changes in leverage, or probability of four discrete outcomes Per. of cash financing, tobit model chg. in inst. holdings/rel. to total Av. miles to portfolio stock Per. of cash financing, tobit model Per. of cash financing, tobit model Per. of cash financing, tobit model 


\section{Independent Variable \\ Ratios (cont.)}

(size of offer)/(offer+capitalization)

Leverage

Leverage

Leverage

Leverage

Leverage

Repurchases/book

Book-value leverage

Market-value leverages

(sales expenses)/sales

(sales expenses)/sales

\section{EBITDA/total assets \\ $\mathrm{PPE} /$ (total assets) \\ (imports+exports)/(2xGDP) \\ (FDI stock)/GDP}

(Stock market capitalization)/GDP $\log ($ Val. stocks traded)/(mkt. cap.)

Stock market capitalization to GDP

(market assets)/(book assets)

$(\mathrm{CAPEX}) /($ total assets)

(amt. SEO offering) /(market cap.)

(net operating income/(total assets)

(cash flow)/(capital stock)

(issue proceeds)/(firm's equity cap.)

(budget balance)/GDP

(current account balance)/GDP

\section{Author(s)}

Faccio and Masulis Faccio and Masulis

Leary and Roberts

Fang

Drucker and Puri

Ivković and Weisbenner

Grinstein and Michaely

Molina

Molina

Molina

Leary and Roberts

Molina

Molina

Chan, Covrig and $\mathrm{Ng}$

Chan, Covrig and $\mathrm{Ng}$

Chan, Covrig and $\mathrm{Ng}$

Chan, Covrig and $\mathrm{Ng}$

Stulz

Leary and Roberts

Leary and Roberts

Drucker and Puri

Leary and Roberts

Malmendier and Tate

Fang

Gelos and Wei

Gelos and Wei
Topic/Short Title

Payment method, M\&A Payment method, M\&A

Capital structure

Investment bank reps.

Lending, underwriting

Local information

Institutional holdings

Firms' leverage

Firms' leverage

Firms' leverage

Capital structure

Firms' leverage

Firms' leverage

Domestic, foreign biases

Domestic, foreign biases

Domestic, foreign biases

Domestic, foreign biases

Financial Globalization

Capital structure

Capital structure

Lending, underwriting

Capital structure

CEO overconfidence Investment bank reps.

Transparency

Transparency

\section{Dependent Variable}

Per. of cash financing, tobit model Per. of cash financing, tobit model Changes in leverage, or probability of four discrete outcomes 0-1 variables in probit regression or gross spread on issue Underwriters' spreads (percentage), or 0 -1 variables

Av. miles to portfolio stock chg. in inst. holdings/rel. to total $\mathrm{S} \& \mathrm{P}$ ratings

S\&P ratings

S\&P ratings

Changes in leverage, or probability of four discrete outcomes S\&P ratings

S\&P ratings

Domestic bias in share holdings

Domestic bias in share holdings

Domestic bias in share holdings

Domestic bias in share holdings percent of portfolio family-held

Changes in leverage, or probability of four discrete outcomes

Underwriters' spreads (percentage), or 0 -1 variables

Changes in leverage, or probability of four discrete outcomes Capex relative to capital stock 0-1 variables in probit regression, or gross spread on issue residuals from an ICAPM regression residuals from an ICAPM regression 


\section{Independent Variable \\ Ratios (cont.)}

Turnover/(market capitalization)

\section{CAPEX/(total assets)}

(operating inc.)/(interest expense)

(operating income)/(total assets)

(firm debt) - (median industry debt)

(total debt)/(total assets)

(cash flow)/(total assets)

cash/(total assets)

Turnover (first day)/float

\section{Trends}

log of days from IPO to SEO

underwriter

Age of bond issue

$\log (1+$ age at IPO $)$

$\log$ (days from IPO to SEO)

$\log$ (number of issues +1 )

$\log$ (maturity)

years tenure of CEO

time trend

$\log$ (maturity)

Age of firm

Length of loan

$\log$ (fund's age)

$\log (1+$ duration of relationship)

number of years' experience

\section{Author(s)}

Gelos and Wei

Bates

Bates

Bates

Bates

Bates

Bates

Bates

Derrien

Fernando, Gatchev, Spindt

Longstaff, Mithal, Neis

Lungqvist and Wilhelm

Lungqvist and Wilhelm

Yasuda

Yasuda

Malmendier and Tate

Fang

Fang

Drucker and Puri

Drucker and Puri

Cooper, Gulen and Rau

Degryse and Ongena

Clement and Tse

\section{Topic/Short Title}

Transparency

Asset sales

Asset sales

Asset sales

Asset sales

Asset sales

Asset sales

Asset sales

IPO pricing

\section{Underwriting}

Corporate structure Prospect Theory, IPOs

Prospect Theory, IPOs

Bank relationships

Bank relationships

CEO overconfidence

Investment bank reps.

Investment bank reps

Lending, underwriting

Lending, underwriting

Mutual-fund names

Distance, lending

Analysts and herding

\section{Dependent Variable}

residuals from an ICAPM regression

0,1 or 2 in logistic regression

Bates: 0,1 or 2 in logistic regression

oversubscription (a ratio)

measure of rep., lead SEO

Av. non-default component of spread zero-one variable zero-one variable underwriting fees (gross spread) underwriting fees (gross spread)

Capex rel. to capital stock

0-1 variables in probit regression, or gross spread on issue

0 -1 variables in probit regression or gross spread on issue

Underwriters' spreads (percentage), or 0 -1 variables

0 -1 variable as firm changes name loan rate until next revision forecast error scaled by price 


\section{TABLe 2. EMPIRICAl Distribution OF ESTIMATEd SLOPES AND THEIR T-VALUES}

$$
\text { Estimating equation: } \mathbf{y}_{\mathbf{j}, \mathrm{t}}=\mathbf{a}+\mathbf{g} \mathbf{x}_{\mathbf{j t}}+\mathrm{z}_{\mathbf{j} t}
$$

$\begin{array}{clllllll}N=50 & \text { Mean } & \text { Std Dev } & \text { Minimum } & \text { Maximum } & \text { Skewness } & \text { Kurtosis } & G \\ \hat{\mathrm{g}} & 0.017925 & 0.030134 & -0.11968 & 0.15968 & -0.049688 & 0.23034 & 10 \\ \mathrm{t}_{\mathrm{g}} & 0.62424 & 1.03709 & -3.71335 & 4.87423 & -0.010632 & 0.15004 & 10 \\ \hat{\mathrm{g}} & 0.009021 & 0.020962 & -0.071487 & 0.086828 & -0.006906 & 0.030994 & 20 \\ \mathrm{t}_{\mathrm{g}} & 0.44205 & 1.02082 & -3.36093 & 5.10835 & 0.019129 & 0.058199 & 20\end{array}$

$\begin{array}{clllllll}N=100 & & & & & & & \\ \hat{\mathrm{g}} & 0.017817 & 0.020508 & -0.055274 & 0.088754 & -0.002693 & -0.047553 & 10 \\ \mathrm{t}_{\mathrm{g}} & 0.87551 & 1.00638 & -2.68733 & 4.66734 & 0.025024 & -0.031547 & 10 \\ \hat{\mathrm{g}} & 0.008600 & 0.014566 & -0.045487 & 0.061779 & 0.016414 & 0.068855 & 20 \\ \mathrm{t}_{\mathrm{g}} & 0.59697 & 1.00403 & -3.03260 & 4.16482 & 0.026325 & 0.013089 & 20\end{array}$

$\begin{array}{llllllll}N=250 & & & & & & & \\ \hat{\mathrm{g}} & 0.017872 & 0.012940 & -0.027533 & 0.066889 & -0.000553 & 0.0089420 & 10 \\ \mathrm{tg}_{\mathrm{g}} & 1.38726 & 1.00537 & -2.13323 & 5.35359 & 0.015865 & 0.013174 & 10 \\ \hat{\mathrm{g}} & 0.008912 & 0.009057 & -0.022711 & 0.043285 & 0.001831 & 0.030121 & 20 \\ \mathrm{tg}_{\mathrm{g}} & 0.97780 & 0.99604 & -2.54748 & 4.74834 & 0.013053 & 0.073351 & 20\end{array}$

$\begin{array}{llllllll}N=500 & & & & & & & \\ \hat{\mathrm{g}} & 0.017812 & 0.009127 & -0.017902 & 0.055412 & -0.025020 & 0.076102 & 10 \\ \mathrm{t}_{\mathrm{g}} & 1.95686 & 1.00448 & -1.97598 & 5.82773 & -0.017759 & 0.065315 & 10 \\ \hat{\mathrm{g}} & 0.008981 & 0.006512 & -0.019099 & 0.032961 & -0.031441 & -0.022414 & 20 \\ \mathrm{t}_{\mathrm{g}} & 1.39288 & 1.01339 & -3.03511 & 5.21713 & -0.008332 & 0.0021424 & 20 \\ N=1000 & & & & & & & \\ \hat{\mathrm{g}} & 0.017840 & 0.006494 & -0.006220 & 0.052009 & 0.001267 & 0.082935 & 10 \\ \mathrm{tg}_{\mathrm{g}} & 2.77075 & 1.01009 & -0.94148 & 8.29562 & 0.009061 & 0.11612 & 10 \\ \hat{\mathrm{g}} & 0.008907 & 0.004597 & -0.010962 & 0.026877 & -0.026178 & 0.038270 & 20 \\ \mathrm{tg}_{\mathrm{g}} & 1.95214 & 1.00952 & -2.63105 & 5.80972 & -0.021985 & 0.034229 & 20\end{array}$

Notes: $\mathrm{N}$ is the number of firms in the cross section, and $\mathrm{G}$ is the number of periods for which the DGP has run. The DGP is $\mathrm{y}_{\mathrm{j}, \mathrm{t}}=\alpha+\beta \Delta \mathrm{x}_{\mathrm{jt}}+\mathrm{u}_{\mathrm{jt}}$. The data are simulated with the error $\mathrm{u}_{\mathrm{jt}}$ normal and the increment $\Delta \mathrm{x}_{\mathrm{jt}}$ normal. The variances of $\mathrm{y}_{\mathrm{j}, \mathrm{t}}, \Delta \mathrm{x}_{\mathrm{j} \mathrm{t}}$ are set equal to those in the data for 1996 discussed in section $4, \beta$ is set equal to 0.17 , the estimate of $\beta$ for 1996, and the variance of $\mathrm{u}_{\mathrm{j}, \mathrm{t}}$ is then found from the equation for the DGP. Results are for various values of $\mathrm{N}$ and for $\mathrm{G}=10$ or $\mathrm{G}=20$. For each pair of $\mathrm{N}, \mathrm{G}$, the simulations have 10,000 replications. 


\section{Table 3. Percentage Price Appreciation, Explained by Change in Earnings or Level of Earnings}

Panel 3.A. $\Delta \ln \mathrm{P}_{\mathrm{j}, \mathrm{T}}=\mathrm{a}+\mathrm{b} \Delta \ln \mathrm{X}_{\mathrm{j}, \mathrm{T}}+\mathrm{u}_{\mathrm{j}, \mathrm{T}}$

\begin{tabular}{|c|c|c|c|c|}
\hline Variable $^{a}$ & Coefficient & Std. Err. & t-Statistic & Prob. \\
\hline $\mathrm{a}_{1996}$ & 0.065778 & 0.009657 & $6.811125 * * *$ & 0.0000 \\
\hline$\Delta \ln X_{\mathrm{j}, 1996}$ & 0.177701 & 0.012964 & $13.70773 * * *$ & 0.0000 \\
\hline$R^{2}$ & 0.159658 & & & \\
\hline
\end{tabular}

\begin{tabular}{llll} 
Variable $^{\mathrm{b}}$ & \multicolumn{2}{l}{ Coefficient Std. Err. } & t-Statistic \\
$\mathrm{a}_{1995}$ & 0.146954 & 0.010198 & $14.41022^{* * *}$ \\
$\Delta \ln \mathrm{X}_{\mathrm{j}, 1995}$ & 0.156725 & 0.013740 & $11.40638^{* * *}$ \\
$R^{2}$ & 0.120456 & &
\end{tabular}

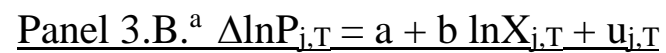

$\begin{array}{lllll}\text { Variable } & \text { Coefficient } & \text { Std. Err. } & \text { t-Statistic } & \text { Prob. } \\ \mathrm{a}_{1996} & 0.067386 & 0.011217 & 6.007421^{* * *} & 0.0000 \\ \ln \mathrm{X}_{\mathrm{j}, 1996} & 0.020529 & 0.010405 & 1.972933^{* *} & 0.0488 \\ R^{2} & 0.003920 & & & \end{array}$

Panel 3.C. Pooled Regression

$\Delta \ln \mathrm{P}_{\mathrm{j}, \mathrm{t}}=\mathrm{a}_{1995} \mathrm{D}_{1995}+\mathrm{a}_{1996} \mathrm{D}_{1996}+\mathrm{b} \Delta \ln \mathrm{X}_{\mathrm{j}, \mathrm{t}}+\mathrm{u}_{\mathrm{j}, \mathrm{t}}$

Variable Coefficient Std. Err. t-Statistic

$\begin{array}{lllll}\mathrm{a}_{1996} & 0.067363 & 0.010966 & 6.143153 * * * & 0.0000 \\ \mathrm{a}_{1995} & 0.146223 & 0.010014 & 14.60209 * * * & 0.0000 \\ \Delta \ln \mathrm{X}_{\mathrm{j}, \mathrm{t}} & 0.166718 & 0.009456 & 17.63162 * * * & 0.0000 \\ R^{2}{ }_{1996} & 0.156602 & R^{2}{ }_{1995} & 0.119967 & \end{array}$

Notes: $\ln X_{j, T}$ is $\log$ earnings, $X_{j, T}>0$, for firm $j$ in the cross-section at time $T$.

a 991 observations. Sample restrictions: $X_{j, 1996}, X_{1995}>0, B_{j, 1995}, B_{j, 1994}>0$

b 1023 observations. Sample restrictions: $X_{j, 1995}, X_{j, 1994}>0, B_{j, 1994,} B_{j, 1993}>0$.

$*, * *, * * *$ Significant at the 10,5 and 1 percent levels.

$\begin{array}{lllll}\text { Variable }^{\mathrm{b}} & \text { Coefficient Std. Err. } & \mathrm{t}-\text { Statistic } & \text { Prob. } \\ \mathrm{a}_{1995} & 0.144483 & 0.011580 & 12.47730^{* * *} & 0.0000 \\ \ln \mathrm{X}_{\mathrm{j}, 1995} & 0.035769 & 0.010974 & 3.259458 * * * & 0.0012 \\ R^{2} & 0.011060 & & & \end{array}$

$\Delta \ln \mathrm{P}_{\mathrm{j}, \mathrm{t}}=\mathrm{a}_{1995} \mathrm{D}_{1995}+\mathrm{a}_{1996} \mathrm{D}_{1996}+\mathrm{b} \ln \mathrm{X}_{\mathrm{j}, \mathrm{t}}+\mathrm{u}_{\mathrm{j}, \mathrm{t}} \quad \mathrm{t}=1995,1996$

Variable Coefficient Std. Err. t-Statistic Prob.

$\begin{array}{lllll}\mathrm{a}_{1996} & 0.066489 & 0.009831 & 6.763507 * * * & 0.0000 \\ \mathrm{a}_{1995} & 0.166273 & 0.011081 & 15.00528 * * * & 0.0000 \\ \ln \mathrm{X}_{\mathrm{j}, \mathrm{t}} & 0.020588 & 0.007390 & 2.786022^{* * *} & 0.0054 \\ R^{2}{ }_{1996} & 0.003920 & R^{2}{ }_{1995} & 0.004017 & \end{array}$




\section{TAble 4. Rates of Return, Regressed on Log Size: Simulation Study}

$\underline{\text { Panel 4.A. Effects of Alternative Sub-Samples }}$

$$
R_{j t}=a+g S_{j t-1}+z_{j t}
$$

$\begin{array}{llllll}\text { Sample } & \text { Slope } & \text { Std. Error } & \text { t-Statistic } & \text { Prob. } & \mathrm{R}^{2} \\ \text { Whole } & -0.016406 & 0.003409 & -4.812320 & 0.0000 & 0.022679 \\ & & & & & \\ \text { Smaller 500 } & 0.000971 & 0.007964 & 0.121879 & 0.9030 & 0.000030 \\ \text { Larger 500 } & -0.003759 & 0.007692 & -0.488689 & 0.6253 & 0.000479 \\ & & & & & \\ \text { Largest 250 } & -0.006195 & 0.013363 & -0.463631 & 0.6433 & 0.000866 \\ \text { Middle 500 } & -0.041741 & 0.013716 & -3.043186 & 0.0025 & 0.018257 \\ \text { Smallest 250 } & -0.010431 & 0.012798 & -0.815052 & 0.4158 & 0.002672\end{array}$

$\underline{\text { Panel 4.B. Comparative Statics Effects of Changes in Parameters }}$

DGP: $\quad \mathrm{R}_{1 \mathrm{t}}=\alpha+\alpha$

$D_{\mathrm{jt}}=\{1,0\}$ as $\mathrm{S}_{1 \mathrm{jt}-1}<\mathrm{S}_{1 \mathrm{mt}-1}$ or $\mathrm{S}_{1 \mathrm{jt}-1} \geq \mathrm{S}_{1 \mathrm{mt}-1}$,

$\mathrm{S}_{1 \mathrm{mt}-1}=$ median of $\mathrm{S}_{1 \mathrm{mt}-1}$

$\alpha=0.00$

$\mathrm{u} 1 \mathrm{jt} \sim \mathrm{N}(0,1)$,

$\mathrm{S}_{1 \mathrm{jt}-1} \sim 10^{1 / 2} * \mathrm{~N}(0,1)$,

$\mathrm{R}_{\mathbf{2 j t}}=2 * \mathrm{R}_{1 \mathrm{jt}}$

$\mathrm{S}_{2 \mathrm{jt}-1}=2 * \mathrm{~S}_{1 \mathrm{jt}-1}$

$\begin{array}{lccccc} & \text { Slope } & \text { Std. Error } & \text { t-Statistic } & \text { Prob. } & \mathrm{R}^{2} \\ \mathrm{R}_{2}, \mathrm{~S}_{2} & -0.016406 & 0.003409 & -4.812320 & 0.0000 & 0.022679 \\ \mathrm{R}_{1}, \mathrm{~S}_{2} & -0.008317 & 0.003394 & -2.450865 & 0.0144 & 0.005983 \\ \mathrm{R}_{2}, \mathrm{~S}_{1} & -0.032584 & 0.003475 & -9.378051 & 0.0000 & 0.080987\end{array}$

Notes: The simulated data for $R_{1 j t}$ and $S_{1 j t-1}$ are the same used in Figure 1. Data are generated for 1,000 firms. The smaller-half firms' $R_{1 \mathrm{jt}}$ are generated as $0.20+\operatorname{IIN}(0,1)$, the larger-half firms' as $-0.20+\operatorname{IIN}(0,1)$. The $\mathrm{R}_{1 \mathrm{jt}}, \mathrm{S}_{\mathrm{ljt}}$ were saved and used to construct the $R_{2 \mathrm{jt}}, S_{2 \mathrm{jt}}$ by multiplying each value by 2 . 


\section{Figure 1. RATES OF RETURN AND LOg Size}

Figure 1. Rates of Return and Log Size

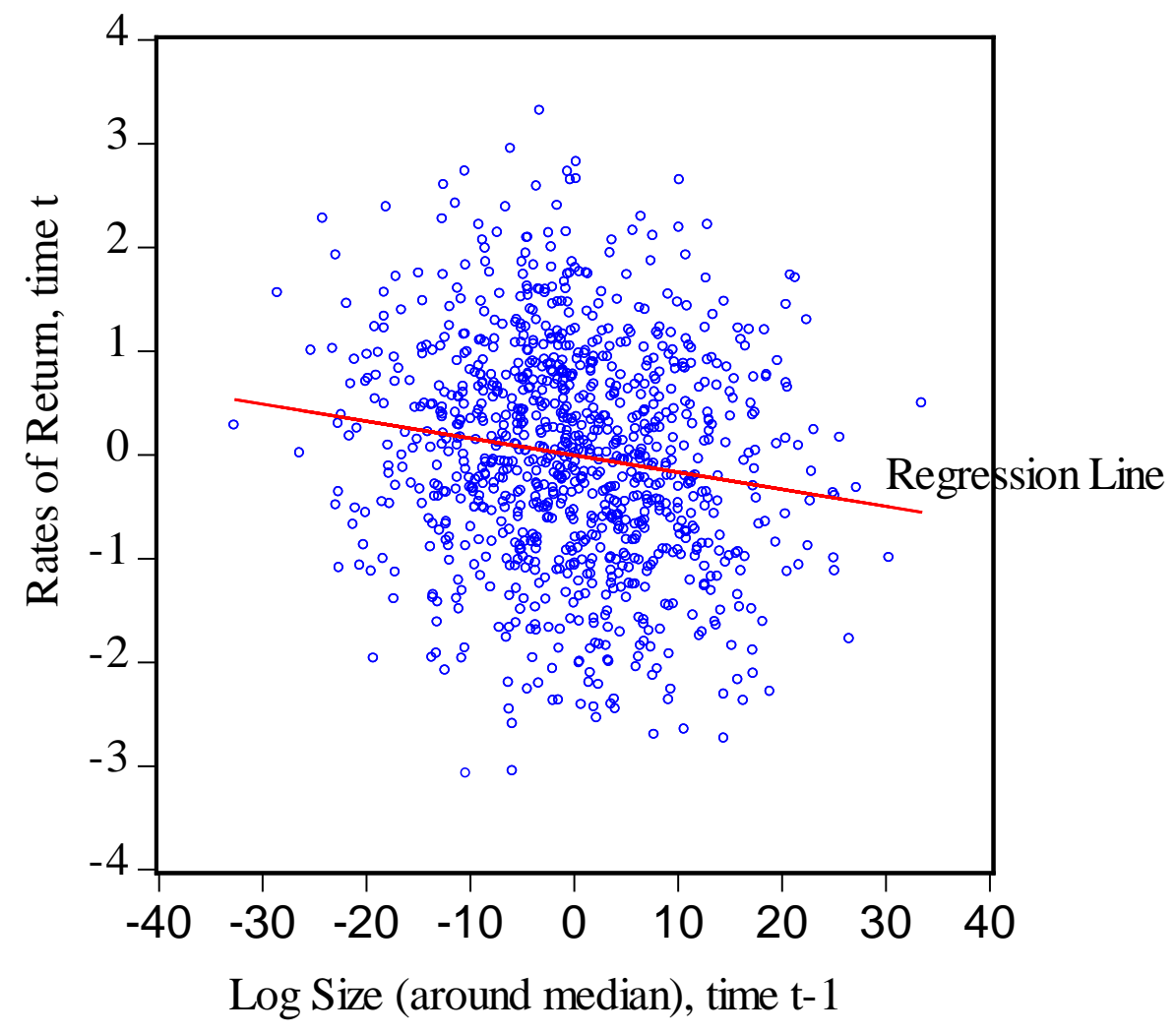

Notes: 1,000 rates of return are generated. For the 500 smallest firms, the DGP is $0.20+\mathrm{N}(0,1)$; for the 500 largest firms, the DGP is $-0.20+\mathrm{N}(0,1)$. For each firm, its initial log size is zero. Each firm has existed for twenty periods, and it growth rate for each period is iid $\mathrm{N}(0,1)$. Log firm size is normalized by subtracting the median value. 